\title{
A Comparative Study of Schools under Government and Private Management with Respect to Academic Achievement and School Resources at Secondary Stage of Education
}

\author{
Dr. Shaikh Ehteshamuddin, Dr. Syed Azaz Ali \\ Assistant professor, DSR college of Education, Aurangabad, Maharashtra, India
}

\begin{abstract}
How to cite this paper: Dr. Shaikh Ehteshamuddin | Dr. Syed Azaz Ali "A Comparative Study of Schools under Government and Private Management with Respect to Academic Achievement and School Resources at Secondary Stage of Education" Published in International Journal of Trend in Scientific Research and Development (ijtsrd), ISSN: 24566470, Volume-3 | Issue-3, April 2019, pp.1558-1560, URL: https://www.ijtsrd.c om/papers/ijtsrd23 454.pdf

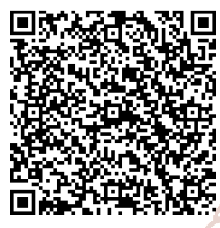

IITSRD23454
\end{abstract}

Copyright (c) 2019 by author(s) and International Journal of Trend in Scientific Research and Development Journal. This is an Open Access article distributed under the terms of the Creative Commons

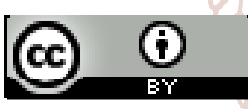
Attribution License (CC BY 4.0) (http://creativecommons.org/licenses/ by $/ 4.0$ )

\section{INTRODUCTION}

Education is one of the most important factors to shape the personality of an individual. It is the potent source of material and human development. Especially the 'Secondary Education' is an indispensable passport to life upon which depends the quality to further education and life. All committees and commissions on education at state, National and International level have stressed upon the role of education in the well being of individual and society at large. India at present is on the fast track of globalization. The decade of nineties have experienced the liberalization of the most of economic activity. In the new millennium, we have already initiated second generation changes in our economic policies. A shift from government sector to private sector is gaining momentum day by bay. So, in the field of education also, private sector seems to flourish due to its inputs (quality) as perceived by most of the parents. Secondary education is of paramount significance for the individual as well as for national development. As such it is an area of major concern in India. Though secondary education, at present is a priority sector in education, this sector has remained neglected in educational research. Especially the area of Socio-Economic-Status (SES) and achievement have not been researched upon extensively in India. A good number of empirical studies in developed countries have been conducted at secondary stage. But in India except for a few studies, make a comparative analysis of achievement directly between government and private schools. At present there is a general trend of private schools both in urban and rural areas in the country. At the same time, there is a quality of research activity at the secondary stage of education in this new scenario in the whole country and particularly in Maharashtra. In Maharashtra a number of studies have been conducted on variables that affect academic achievement like intelligence, creativity, Socio-Economic-Status (SES), teacher, evaluation techniques, use of educational technology and giftedness etc. only one comparative study between private and government was conducted by Geeta (1994) private unaided junior school were significantly more cost effective either than Govt. \& private aided junior schools. Besides, in the contemporary educational research, there exists a lack of research activity regarding involvement of private school education especially at secondary stage. In the back drop the investigator, observing such a lack of educational research at secondary stage of education in view 
of felt need and found solid reasons to conduct Study that will attempt to give a clear picture, about the comparative status of private and government schools with respect to achievement and SES of the parents attracts serious attraction in present study.

The research in secondary education has mostly remained confined within the developed countries and especially in USA and UK till the nineteenth sixties. As regards to developing countries and particularly in India research in secondary education not providing healthy sign. A bibliography of research brought out by NCERT (Dave, P.N. and Murthy C.V.G., 1994) revealed that out of 1800 research abstracts only 54 studies were carried on secondary education. The investigator scanned the available literature on the subject that pertained to the variable in question. The critical analysis of these studies gave rise to certain substantial enquiries which needed to be highlighted and addressed to for the sake of further investigation. Most of the studies whether conducted in India or abroad support multiple results leading to a phenomenon where the need for further research becomes imperative. The contrary findings of various studies mentioned above inspired the investigator to conduct a study of comparative nature between private and government schools with respect to certain variables like Socio-Economic-Status (S-E-S) and academic achievement at secondary stage of education. The most important studies conducted in India and abroad that pertain to be variables in question are that of Kulkarni \& others (1970): observed that boys achieved higher than girls, the SES condition of the parents of school type (e.g. Govt. or private management) provided better teaching learning situations. Geeta (1994): in her study found that private unaided junior school were significantly more cost effective either than Govt. \& private aided junior schools. She also found that students in private un-aided junior school perform significantly better on test of reading \& mathematics than students in Government \& private aided schools. Das, R.C. (1974): The study revealed that there was significant relationship between efficiency in education and physical facilities in schools. Varghese, N.V (1994): conducted a study on DPEP program on learner achievement and school quality which found that schools managed by private sector show marginally better performance than government schools, parental education and occupation are also important factors associated with learner achievement. Singh \& Saxena (1995): attempted to study the effects of school related variables from pupil achievement main results are at the school level the mean S-E-S is positively associated with the math's \& language. The factors of educational \& physical facilities in school have positive association with school mean achievement in mathematics. Ercikan, et.al (2005): found that parent's highest education level was the highest predictor of achievement. Student home environment related variables were stronger predictor of achievement.

\section{OBJECTIVES:}

1. To compare the academic achievement of students enrolled in private and government secondary schools.

2. To compare the academic achievement of students of both schools on gender basis.

3. To compare the School resources available in both types of schools.

\section{HYPOTHESES:}

1. The achievement level of private school students is far better than government school students.

2. Government school students differ in academic achievement on gender basis.

3. Private school students differ in academic achievement on gender basis.

4. The resources of private school is better than Government school.

\section{Research tools:}

Following tools will be implied for gathering data needed for the present study.

1. School resources questionnaire made by researchers.

2. The measure of academic achievement is based on the marks obtained in the VIII ${ }^{\text {th }}$ grade examination conducted by the school.

\section{Methodology:}

The Research is conducted in Aurangabad, Nanded and Parbhani districts of Maharashtra state. 40 secondary schools are selected as a sample with stratified random sampling technique.20 schools were Government and 20 schools were private. Out of the sample of 1567 students 770 students were Government secondary school students and 797 students from private secondary schools. Academic achievement score of all students of IXth class is collected by the final marks of VIIIth class from their school register records under the supervision of respective head masters of that schools. School resources score is obtained from questionnaire. For the analysis of data researcher used descriptive and inferential statistics. Researcher used central tendency (mean), standard deviation (SD), t-test for significant difference between two means and Pearson's chisquare technique under the guidance of renowned statistician.

Findings and conclusion:

Hypothesis 1: The achievement level of private school students is far better than government school students.

Table 5.1:

\begin{tabular}{|c|c|c|c|c|c|}
\hline Type of school & $\mathbf{N}$ & mean & S.D & df & t-Value \\
\hline Govt & 770 & 59.95 & 7.56 & & \multirow{2}{*}{$5.84^{* *}$} \\
\hline Pvt & 797 & 58.93 & 8.64 & 1565 & 2.87 \\
\hline
\end{tabular}

**significant

The total number of Government and private secondary school students were $770 \& 797$ respectively as indicated by the table 5.1. out of 100 scores; the mean achievement scores in academic achievement of Government school students is 59.95 and standard deviation ( $\mathrm{SD}=7.56$ ); In case of Private school students the mean academic achievement score is 58.93 and standard deviation $(S D=8.64)$ respectively. The statistically calculated t-value is 2.84; which is significant at 0.01 level of confidence with $1565 \mathrm{df}$. The results clearly indicates that there is a significant difference between mean academic achievement scores of Government and Private secondary school students. Both are not equally good they differ in their academic achievement, private school students are not performing far better than their opponent Government school students also performing better then private school students Thus the First hypothesis stating that "the achievement level of Private school students is far better than Government school students" is rejected at 0.01 level of confidence. 
Hypothesis 2: Government school students differ in academic achievement on gender basis.

Table 5.2:

\begin{tabular}{|c|c|c|c|c|c|}
\hline $\begin{array}{c}\text { Type of school } \\
\text { (govt) }\end{array}$ & $\mathrm{N}$ & mean & S.D & df & t-Value \\
\cline { 1 - 4 } Male & 386 & 60.44 & 7.62 & & \\
\cline { 1 - 4 } Female & 383 & 59.00 & 6.61 & 767 & $2.79 * *$ \\
\hline
\end{tabular}

**signific

The total number of male and female Government secondary school students were 386 and 383 respectively as indicated by table number 5.2. out of total 100 scores the mean academic achievement score of male Government secondary school student is 60.44 and standard deviation (SD=7.62) and in case of female Government secondary school students the mean academic achievement score is 59.00 and standard deviation $(\mathrm{SD}=6.61)$ respectively; the calculated $\mathrm{t}$-value is 2.79 ; with $767 \mathrm{df}$. which is significant at 0.01 level. The result shows that there is a significant difference between academic achievement of male and female students of Government schools. Males are performing better than females in Government schools. thus the hypothesis " Government school students differ in academic achievement on gender basis" is accepted at 0.01 level of confidence.

Hypothesis 3: Private secondary school students differ in academic achievement on gender basis.

Table 5.3:

\begin{tabular}{|c|c|c|c|c|c|}
\hline $\begin{array}{c}\text { Type of school } \\
\text { (Pvt) }\end{array}$ & N & mean & S.D & df & t-Value \\
\hline Male & 384 & 59.45 & 7.49 & & ntelati \\
\hline Female & 414 & 58.86 & 6.68 & 796 & $1.18^{*}$ \\
\hline
\end{tabular}

*Not significant

The total numbers of male and female Private secondary school students were 384 and 414 respectively as indicated by table number 5.3. out of total 100 scores the mean academic achievement score of male Private secondary school student is 59.45 and standard deviation ( $\mathrm{SD}=7.49$ ) and in case of female Private secondary school students the mean academic achievement score is $\mathbf{5 8 . 8 6}$ and standard deviation $(\mathrm{SD}=6.68)$ respectively; the calculated $\mathrm{t}$-value is 1.18; with 796df. Which is not significant at 0.01 level. The result shows that there is no significant difference between academic achievement of male and female students of Private schools. Both are equally performing in Private schools on academic achievement basis. thus the hypothesis "Private school students differ in academic achievement on gender basis" is rejected at 0.01 level of confidence".

Hypothesis 4: The resource of private school is better than Government school.

Table 5.4:

\begin{tabular}{|c|c|c|c|}
\hline \multirow{2}{*}{$\begin{array}{c}\text { School resources \% } \\
\text { within both school type }\end{array}$} & \multicolumn{2}{|c|}{ School } & \\
\cline { 2 - 4 } HIGH & Govt & Pvt & Total \\
\hline \multirow{2}{*}{ AVERAGE } & 102 & 145 & 247 \\
& $13.2 \%$ & $18.2 \%$ & $15.8 \%$ \\
\hline \multirow{2}{*}{ LOW } & 365 & 564 & 929 \\
& $47.4 \%$ & $70.8 \%$ & $59.3 \%$ \\
\hline \multirow{2}{*}{ Total } & 303 & 88 & 391 \\
& $39.4 \%$ & $11 \%$ & $25 \%$ \\
\hline & 770 & 797 & 1567 \\
& $100 \%$ & $100 \%$ & $100 \%$ \\
\hline
\end{tabular}

Chi-square $=167.92{ }^{* *}$ significant at 0.01 level.
The total number of Government and private secondary school students were $770 \& 797$ respectively as indicated by the table 5.4. out of 770 Government school students 102 students falls in high resource category which is $13.2 \%$; 365 students comes in average resource category which is 47.4\%; 303 students belongs to low resource category which is $39.4 \%$ respectively where as out of 797 Private school students 145 students falls in high resource category which is $18.2 \%$; 564 students comes in average resource category which is $70.8 \%$; 88 students belongs to low resource category which is $11 \%$ respectively. The Pearson's chi-square is 167.92 which is significant at 0.01 level. so there is a significant difference between resource of students of both type of schools. most private school student comes from high resource category whereas most Government School students comes from low resource category. Thus the hypothesis "The resource of private school is better than Government school." is accepted at 0.01 level of confidence.

\section{Educational implication:}

This study is very helpful for parents, school teachers, principals and policy makers. It will assist parents where to admit their children as well as teachers and principal understand the difference of S-E-S and will equally care all students. Policy makers with the help of this study can form better teaching learning process. It will help school authorities in academic achievement enhancement and ways to promote teaching learning process among students.

References:

[1] Kulkarni, S. S. and others (1970). All India survey of achievement in mathematics, national council of educational research and training, New Delhi.

[2] Geeta, G. K. (1994). An economics evaluation of management types in urban India: A case study of U.P., Ph.D. (Dissertation) London: Oxford University.

[3] Bashir, Sajitha (1994). Achievement performance at the primary level in public and private schools of Tamilnadu: preliminary analysis using ordinary least squares, New Delhi: Indian educational review. (V.29) National council of educational Research and Training.

[4] Behrman et. Al (1997). School quality and cognitive achievement production: A case study of rural Pakistan, great Britain: Economics of educational Review V.16, N.2.

[5] Das, R. C. (1974). Impact of school condition on primary education, Assam state Institute of Education.

[6] Varghese, N. V. (1994). School quality and student learning: a case study of primary school in Kerala, New Delhi National Institute o Educational administration and planning.

[7] Singh \& Saxena (1995). Achievement difference and school effects, New Delhi: Indian Educational Review, V. 31. No.1. NCERT.

[8] Ercikan, Mccreith, Tanya; Lapointe, Vanessa I (2005). factors associated with mathematics achievement and participation in advanced mathematics courses: an examination of gender differences from and international perspective school science and mathematics. 